\title{
DIVUSI INOVASI PENILAIAN PEMBELAJARAN HIGHER ORDER THINKING SKILL (HOTS) PADA SEKOLAH DASAR
}

\author{
Rizal $^{1}$, Surahman $^{2}$, Moh Aqil $^{3}$, Azizah $^{4}$ \\ 1,2,3,4 Universitas Tadulako, Palu, Indonesia \\ risrizal666@gmail.com, ${ }^{2}$ surahmanwilade@gmail.com, ${ }^{3}$ mohaqil555@gmail.com, \\ 4azizahrosnadi@gmail.com
}

\begin{abstract}
ABSTRAK
Standar penilaian sekolah dasar di Kabupaten Donggala hanya berada pada level 2 mencapai $2.59 \%$ (kategori rendah). Hal ini terjadi, karena penerapan keterampilan berpikir tingkat tinggi pada sekolah Dasar di Kabupaten Donggala khususnya Kecamatan Banawa tidak optimal. Sehingga penelitian dilakukan untuk mengungkapkan data kemampuan guru didalam melaksanakan penilaian pembelajaran berorientasi HOTS. Penelitian ini menggunakan pendekatan kuantitatif dan kualitatif. Penelitian ini di laksanakan Sekolah Dasar Kecamatan Banawa, Kabupaten Donggala dengan penentuan sampel menggunakan purposive sampling. Pengumpulan data dilakukan dengan angket dan wawancara. Teknik analisis data yaitu pengumpulan data, reduksi data, penyajian data, dan verifikasi. Hasil penelitian menunjukkan bahwa dari 30 Sekolah Dasar yang ada di Kecamatan Banawa hanya 13 sekolah atau $45 \%$ yang telah mengenal dan memperoleh informasi tentang penilaian pembelajaran berorientasi HOTS. Disimpulkan bahwa (1) Penilaian pembelajaran berorientasi HOTS di SD se Kecamatan Banawa belum difahami (2) pemerintah dan stake holder serta pihak sekolah belum memanfaatkan saluran informasi yang ada untuk menyampaikan dan bertukar informasi tentang HOTS, (3) diperlukan cukup waktu untuk menyalurkan informasi tentang HOTS agar terbentuk difusi inovasi (4) dalam hal ini sistem sosial atau kerja kelompok guru (KKG) belum menjadi wadah dalam menyalurkan informasi tentang penilaian HOTS di SD se Kecamatan Banawa Kabupaten Donggala.
\end{abstract}

Kata Kunci: divusi inovasi, penilaian higher order thinking skill

\section{INNOVATION DIVISION OF HIGHER ORDER THINKING SKILL (HOTS) LEARNING ASSESSMENT IN BASIC SCHOOLS}

\begin{abstract}
The standard of assessment for elementary schools in Donggala Regency is only at level 2 reaching 2.59\% (low category). This happens, because the application of higher-order thinking skills in elementary schools in Donggala District, especially Banawa District, is not optimal. So the research was conducted to reveal data on the ability of teachers in carrying out HOTS-oriented learning assessments. This study uses a quantitative and qualitative approach. This research was carried out by the Elementary School in Banawa District, Donggala Regency by determining the sample using purposive sampling. Data was collected by means of questionnaires and interviews. Data analysis techniques are data collection, data reduction, data presentation, and verification. The results showed that of the 30 elementary schools in Banawa District, only 13 schools or $45 \%$ had known and obtained information about HOTS-oriented learning assessment. It was concluded that (1) the assessment of HOTS-oriented learning in elementary schools throughout Banawa sub-district was not yet understood (2) the government and stake holders as well as the school had not utilized the existing information channels to convey and exchange information about HOTS, (3) sufficient time was needed to distribute information about HOTS. HOTS in order to form a diffusion of innovation (4) in this case the social system or teacher group work (KKG) has not become a forum for distributing information about HOTS assessment in elementary schools throughout Banawa District, Donggala Regency.
\end{abstract}

Keywords: divusion of innovation, higher order thinking skill assessment

\begin{tabular}{|c|c|c|}
\hline Submitted & Accepted & Published \\
\hline 01 Maret 2021 & 19 Oktober 2021 & 29 November 2021 \\
\hline
\end{tabular}

\begin{tabular}{|l|l|l|l|}
\hline Citation & $:$ & $\begin{array}{r}\text { Rizal, R., Surahman, S., Aqil, M., \& Azizah, A. (2021). Divusi Inovasi Penilaian Pembelajaran Higher Order Thinking } \\
\text { Skill (Hots) Pada Sekolah Dasar. Jurnal PAJAR (Pendidikan dan Pengajaran), 5(6), 1816-1824. DOI : } \\
\text { http://dx.doi.org/10.33578/pjr.v5i6.8345. }\end{array}$ \\
\hline
\end{tabular}

\section{PENDAHULUAN}

Era Abad ke-21 menjadikan perbaikan mutu Pendidikan sangat penting untuk menjamin peserta didik memiliki keterampilan belajar dan berinovasi. Pembelajaran harus memberikan desain yang lebih otentik untuk melalui tantangan dimana peserta didik dapat berkolaborasi menciptakan solusi memecahkan masalah dalam kehidupannya. Karenananya Kurikulum 2013 
menghendaki agar peserta didik memiliki kemampuan berpikir HOTS (Higher Order Thinking Skill). Para peserta didik dikembangkan untuk belajar berpikir tingkat tinggi. Guru tidak lagi memberitahu peserta didik, melainkan peserta didik harus mencari tahu, berpikir cerdas dan kreatif yang berarti berpikir tingkat tinggi. Pengembangan penilaian pembelajaran berorientasi pada keterampilan berpikir tingkat tinggi atau Higher Order Thinking Skill (HOTS) merupakan program yang dikembangkan dalam upaya peningkatan kualitas pembelajaran dan meningkatkan kualitas lulusan, pada Keterampilan Berpikir Tingkat Tinggi atau Higher Order Thinking Skill (HOTS) yang dijabarkan dalam kemampuan berpikir kritis (criticial thinking), kreatif dan inovasi (creative and innovative), kemampuanberkomunikasi (communication skill), kemampuan bekerja sama (collaboration) dan kepercayaan diri (confidence). Lima hal yang menjadi target karakter peserta didik itu melekat pada sistem evaluasi dalam ujian nasional dan merupakan kecakapan abad 21.

Melihat kenyataan saat ini, banyak peserta didik belum memiliki kemampuan berpikir tingkat tingi, masih pada kemampuan menghafal. Berdasarkan data yang LPMP Sulawesi Tengah (2015-2019) standar penilaian sekolah dasar dikabupaten Donggala hanya berada pada level 2 mencapai $2.59 \%$. Padahal kemampuan berpikir tingkat tinggi (Higher Order Thinking Skill) wajib dimiliki oleh setiap peserta didik yang diharapkan dapat memeriksa, menganalisis, atau mengevaluasi setiap informasi yang didapatkan sehingga sesuai dengan masalah yang perlu diselesaikan. Selain itu, melalui kegiatan berpikir tingkat tinggi siswa dapat melatih diri untuk bekerja sama dengan baik dalam suatu kelompok diskusi. Kegiatan tersebut juga dapat membiasakan siswa untuk berkomunikasi dengan baik sehingga siswa dapat mengungkapkan pendapat atau opininya baik secara lisan atau tulisan. Melalui kegiatan berpikir tingkat tinggi, siswa juga diberi kebebasan dalam menyelesaikan masalah, menyampaikan ide, dan pertanyaan sehingga siswa memiliki pemikiran yang lebih kreatif

Penerapan keterampilan berpikir tingkat tinggi di Indonesia masih memiliki beberapa permasalahan, salah satunya adalah kompetensi guru. Berdasarkan data LPMP Sulawesi Tengah (2015-2019) hasil uji kompetensi berada di angka $47.23 \%$., dengan kategori rendah. walaupun pemerintah sendiri sudah melakukan banyak perubahan dan perbaikan dan para pendidik diharapkan agar mengetahui lebih lanjut tingkat penerapan pembelajaran yang berorientasi pada berpikir tingkat tinggi. Sehingga penelitian dilakukan untuk mengungkapkan data kemampuan guru didalam menyamakan persepsi dan melaksanakan penilaian pembelajaran HOTS pada sekolah dasar dikabupaten Donggala.

\section{KAJIAN TEORETIS}

Teori Difusi Inovasi menjelaskan proses bagaimana suatu inovasi dikomunikasikan lewat channel tertentu sepanjang waktu kepada anggota kelompok dari suatu sistem sosial. "Diffusion is the process by which an innovation is communicated through certain channels over time among the members of a social system." (Rogers, 1983). Sesuai dengan pemikiran Rogers, dalam proses difusi inovasi terdapat 4 (empat) elemen pokok, yaitu: Inovasi, Saluran Komunikasi, Jangka Waktu, dan Sistem Sosial. Inovasi adalah gagasan, tindakan, atau barang yang dianggap baru oleh seseorang. Kebaruan inovasi itu diukur secara subjektif, menurut pandangan individu yang menangkapnya. Saluran komunikasi adalah 'alat untuk menyampaikan pesan-pesan inovasi dari sumber ke penerima. Hal yang terpenting dalam difusi adalah adanya pertukaran informasi antara satu orang dengan lainnya atau lebih untuk mengomunikasikan ide baru tersebut. Saluran komunikasi yang digunakan akan sangat berpengaruh terhadap seberapa besar efek dari pertukaran informasi tersebut sehingga diperlukan ketepatan dalam memilih atau menggunakannya. Kondisi kedua belah pihak yang akan bertukar informasi pun perlu diperhatikan karena memengaruhi keefektifan penyampaian pesan.

Inovasi pembelajaran dapat diartikan sebagai suatu upaya baru dalam proses interaksi peserta didik dengan pendidik, dengan menggunakan berbagai metode, pendekatan, sarana dan suasana yang mendukung untuk proses pengumpulan dan pengolahan informasi untuk mengukur Keterampilan berpikir tingkat tinggi 
siswa, yang tidak hanya membutuhkan kemampuan mengingat saja, namun membutuhkan kemampuan lain yang lebih tinggi, seperti kemampuan berpikir kreatif dan kritis (Desstya, 2015). Sehingga HOTS atau keterampilan berpikir tingkat tinggi merupakan kemampuan menghubungkan, memanipulasi, dan mentransformasi pengetahuan serta pengalaman yang sudah dimiliki untuk berpikir secara kritis dan kreatif dalam upaya menentukan keputusan dan memecahkan masalah pada situasi yang baru dan itu semua tidak dapat dilepaskan dari kehidupan sehari-hari (Pratama \& Istiyono, 2015). Maka dapat disimpulkan bahwa keterampilan berpikir tingkat tinggi yaitu keterampilan berpikir secara kritis dan kreatif sesuai dengan pengalaman belajar yang sudah diperoleh.

Indikator untuk mengukur kemampuan berpikir tingkat tinggi pada tingkat analisis yaitu fokus pada ide utama, menganalisis argumen, serta membandingkan dan mengkontraskan. Indikator untuk mengukur kemampuan evaluasi yaitu kemampuan mengambil keputusan atau metode agar sejalan dengan tujuan yang diinginkan. Brookhart (dalam Kurniati dkk, 2014) mengungkapkan bahwa indikator untuk mengukur kemampuan kreasi atau mencipta yaitu menyelesaikan soal dengan solusi lebih dari satu, merancang suatu cara untuk menyelesaikan masalah, dan membuat sesuatu yang baru.

Penilaian hasil belajar pada kurikulum 2013 dilakukan secara menyeluruh terhadap kompetensi sikap, pengetahuan, dan keterampilan oleh karena itu pemerintah sudah mengolah kompetensi yang disusun oleh Krathwohl \& Anderson dalam Pemendikbud nomor 104 Tahun 2014. Berikut adalah sasaran penilaian hasil belajar oleh pendidik pada kemampuan kognitif menurut Anderson (dalam Mulyana, Iskandar, \& Aryani: 2016):

a) Mengetahui

b) Memahami

c) Menerapkan atau Mengaplikasi

d) Menganalisis

e) Mengevaluasi

f) Mencipta

Berdasarkan beberapa indikator yang dijabarkan di atas, peneliti memutuskan untuk menggunakan indikator tersebut saat melakukan analisis terhadap perencanaan dan penilaian pembelajaran. Perencanaan dan penilaian pembelajaran dinyatakan memuat keterampilan berpikir tingkat tinggi jika menggunakan kata kerja operasional keterampilan berpikir tingkat dalam tingkatan menganalisi, mengevaluasi, dan mengkreasi. Yang mencakup: penilaian otentik, penilaian diri, penilaian berbasis portofolio, ulangan, ulangan harian, ulangan tengah semester, ulangan akhir semester, ujian tingkat kompetensi, ujian mutu tingkat kompetensi, ujian nasional, dan ujian sekolah/madrasah.

\section{State Off Art}

Inovasi pendidikan harus dapat diadaptasi oleh guru, sehingga dapat mengikuti pembelajaran abad 21, sehingga dibutuhkan kemauan untuk menyamakan persepsi terhadap suatu inovasi. Menurut Rogers, (1983), "as the process by which participants create and share information with one another to reach mutual understanding", atau suatu proses di mana orang yang terlibat di dalamnya menciptakan dan berbagi informasi satu sama lain agar terdapat penyamaan persepsi. Hal yang terpenting dalam difusi adalah adanya pertukaran informasi antara satu orang dengan lainnya atau lebih untuk mengomunikasikan ide baru tersebut. Saluran komunikasi yang digunakan akan sangat berpengaruh terhadap seberapa besar efek dari pertukaran informasi tersebut sehingga diperlukan ketepatan dalam memilih atau menggunakannya. Kondisi kedua belah pihak yang akan bertukar informasi pun perlu diperhatikan karena memengaruhi keefektifan penyampaian pesan. Sehingga guru dapat menyamakan persepsi tentang penilaian pembelajaran berientasi HOTS dan saling mengkomunikasikan secara bersamasama dapat mengadaptasi suatu inovasi pendidikan. Kegagalan adaptasi suatu inovasi, karena faktor tidak tersedianya saluran komunikasi yang tepat, sehingga suatu inovasi tidak dapat difahami oleh guru serta tidak dapat dilaksanakan.

\section{METODE PENELITIAN}

\section{a. Jenis Penelitian}

Penelitian ini menggunakan dua pendekatan, yaitu kuantitatif dan kualitatif dengan pola "the dominant-less dominat design". Bagian pertama, menggunakan pendekatan kuantitatif, 
yakni melalui metode survei. Langkah berikutnya penelitian ini menggunakan paradigma tambahan (kurang dominan) dengan pendekatan kualitatif untuk pendalaman. Pada tahap ini ditambahkan teknik wawancara. Instrumen yang digunakan untuk pengumpulan data kuantitatif diantaranya, yaitu angket dan wawancara.

\section{b. Prosedur Penelitian}

Prosedur langkah-langkah dalam penelitian ini adalah sebagai berikut: 1) Tahap Pendahuluan; pada tahap ini preneliti melakukan studi lapangan dan mencari informasi terkait dengan permasalahan dan fenomena penilaian pembelajaran berorientasi HOTS. Selanjutnya peneliti melakukan studi literature lebih mendalam tentang teknik penilaian pembelajaran berorientasi HOTS. 2) Tahap Pelaksanaan; pada tahap ini peneliti menyebarkan angket untuk penilaian pembelajaran berorientasi HOTS pada guru agar data yang didapat lebih akurat. 3. Tahap Akhir. Setelah ketiga tahap telah dilakukan maka tahap terakhir yaitu menganalisis dan menyusun laporan. Pada tahap ini peneliti menggunakan perhitungan statistik untuk menghitung hasil angket penilaian pembelajaran berorientasi HOTS berdasarkan data yang diperoleh.

\section{c. Waktu dan Tempat Penelitian}

Penelitian ini dilaksanakan pada bulan Juli sampai September 2020 dan Lokasi yang digunakan dalam penelitian ini adalah Sekolah Dasar Kabupaten Donggala. Populasi penelitian ini adalah Sekolah Dasar di Kabupaten Donggala yang berjumlah 341 SD. Sampel ditentukan dengan menggunakan teknik cluster sampling, proportional atau pengambilan sampel secara kelompok, adapun sampel dalam penelitian ini yaitu SD Se Kecamatan Banawa Kabupaten Donggala.

\section{d. Instrumen Penelitian}

Adapun instrumen yang digunakan pada penelitian ini adalah lembar observasi, angket penilaian pembelajaran berorientasi HOTS dan pedoman wawancara.

\section{e. Analisis Data}

Pengumpulan data, 2. Reduksi data, 3. Penyajian data, 4. Verifikasi. Sementara data yang berupa angka ditabulasi dengan persentase, ditampilkan dalam bentuk tabel dan diagram.

\section{HASIL DAN PEMBAHASAN}

Dalam Penelitian ini dilaksanakan untuk mengetahui adanya difusi inovasi penilaian pembelajaran Higher Order Thingking Skill (HOTS) di sekolah dasar SD se Kecamatan Banawa. Jumlah sekolah yang menjadi sampel penelitian ini yaitu 30 sekolah, peneliti menyebar kuisioner ke sekolah-sekolah untuk memperoleh data tentang difusi inovasi penilaian pembelajaran. Terdapat 4 indikator difusi inovasi penilaian HOTS dalam penelitian ini. Indikator tersebut yaitu informasi tentang penilaian pembelajaran HOTS, pelaksanaan penilaian, hambatan dalam penilaian, dan hasil yang diperoleh dari penilaian pembelajaran HOTS. Berdasarkan hasil sebaran angket, diperoleh 55\% responden belum memperoleh informasi tentang penilaian pembelajaran berbasis HOTS. Sebesar 45\% responden telah mengetahui serta melaksanakan penilaian pembelajaran berbasis HOTS.

Tabel 1. Analisis Hasil Angket Difusi Inovasi Penilaian Pembelajaran HOTS

\begin{tabular}{lllc}
\hline No & \multicolumn{1}{c}{ Item Pertanyaan } & Ya & Tidak \\
\hline 1 & $\begin{array}{l}\text { Apakah Bapak/Ibu telah memperoleh informasi tentang Penilaian } \\
\text { Pembelajaran HOTS? }\end{array}$ & $40 \%$ & $60 \%$ \\
2 & $\begin{array}{l}\text { Informasi tentang Penilaian Pembelajaran HOTS itu apakah } \\
\text { dikomunikasikan oleh pemerintah setempat? }\end{array}$ & $30 \%$ & $70 \%$ \\
3 & $\begin{array}{l}\text { Apakah Penilaian Pembelajaran HOTS adalah sesuatu yang baru, } \\
\text { meresahkan dan sulit untuk dipahami dan dilaksanakan? }\end{array}$ & $65 \%$ & $35 \%$ \\
4 & $\begin{array}{l}\text { Apakah terdapat hambatan ketika Penilaian Pembelajaran HOTS ini } \\
\text { dikomunikasikan? }\end{array}$ & $60 \%$ & $40 \%$ \\
5 & $\begin{array}{l}\text { Apakah telah terjalin pertukaran informasi tentang Penilaian } \\
\text { Pembelajaran HOTS dikalangan para guru? }\end{array}$ & $30 \%$ & $70 \%$
\end{tabular}




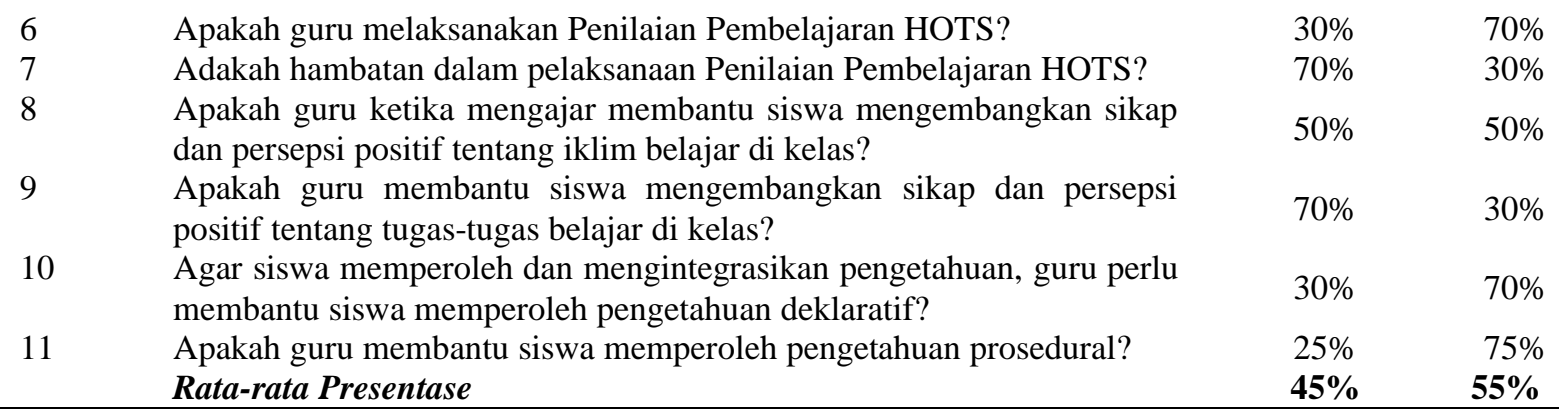

Berdasarkan tabel 1 dapat dijelaskan
bahwa proses difusi inovasi penilaian
pembelajaran HOTS di sekolah dasar se
Kecamatan Banawa belum maksimal, hal ini dapat
dilihat dari presentase jawaban yang terdapat pada
kuisioner yaitu hanya 45\% guru yang telah
memperoleh memperoleh informasi tentang
Penilaian Pembelajaran HOTS.

Adapun hasil wawancara yang diperoleh dari informan sebagai berikut;

1. Apakah Bapak/Ibu telah memperoleh informasi tentang Penilaian Pembelajaran HOTS? Jawaban: "Iya, informasi diperoleh dari kegiatan $K K G$ "

2. Bagaimana informasi tentang Penilaian Pembelajaran HOTS itu dikomunikasikan? Jawaban: "Sebelum memberikan informasi tentang penilaian pembelajaran HOTS terlebih dahulu guru mempersiapkan RPP, pemetaan dan perangkat pembelajaran lainnya untuk dijadikan panduan bagi guru dalam melaksanakan proses pembelajaran"

3. Apakah Penilaian Pembelajaran HOTS adalah sesuatu yang baru, meresahkan dan sulit untuk dipahami dan dilaksanakan? Jawaban: " $Y a$, karena sebagian besar siswa sulit memahami pembelajaran soal HOTS, karena dibutuhkan kemampuan siswa untuk untuk memecahkan masalah secara mandiri dengan kemampuan berpikir secara kritis dan kreatif'.

4. Apakah terdapat hambatan ketika Penilaian Pembelajaran HOTS dikomunikasikan? Jawaban: "Ya, faktor yang menghambat adalah; lingkungan keluarga yang kurang mendukung dan fasilitas sekolah yang kurang memadai".

5. Apakah telah terjalin pertukaran informasi tentang Penilaian Pembelajaran HOTS dikalangan para guru? Jawaban: "Tidak, sebagian besar guru belum menerima informasi tentang penilaian pembelajaran HOTS".

6. Bagaimana guru melaksanakan Penilaian Pembelajaran HOTS? Jawaban: "Disesuaikan dengan ukuran kemampuan siswa".

7. Adakah hambatan dalam pelaksanaan Penilaian Pembelajaran HOTS? Jawaban: "Ya, sebab kurangnya kemampuan siswa untuk berpikir kritis".

8. Apakah guru ketika mengajar membantu siswa mengembangkan sikap dan persepsi positif tentang iklim belajar di kelas? Bagaimana penilaiannya? Jawaban: " $Y a$, dengan cara mengecek kehadiran siswa, sikap siswa dalam kelas, mengecek kerapian siswa, mematuhi peraturan dan perintah yang diterapkan guru".

9. Apakah guru membantu siswa mengembangkan sikap dan persepsi positif tentang tugas-tugas belajar di kelas? Ceritakan proses penilaiannya. Jawaban: " $Y a$, proses penilaian HOTS pendekatan saintifik $(5 \mathrm{~m})$ yang meliputi; mengamati, menanya, mengumpulkan informasi, menalar dan mengkomunikasikan sehingga mampu mengubah iklim pembelajaran menjadi lebih aktif, kolaboratif dan partisipatif sehingga merangsang kemampuan berpikir kritis dan analisis siswa".

10. Agar siswa memperoleh dan mengintegrasikan pengetahuan, guru perlu membantu siswa memperoleh pengetahuan deklaratif? Penilaian seperti apa yang anda gunakan untuk melakukan penilaian deklaratif? Jawaban: "dengan menggunakan penilaian tes tertulis, tes lisan, dan penugasan". 
11. Apakah guru membantu siswa memperoleh pengetahuan prosedural? Jelaskan proses penilaiannya. Jawaban: "Ya, proses menentukan tinjauan, menyusun kisi-kisi perumusan indikator pencapaian, penyusunan instrumen, telaah instrumen, pelaksanaan penilaian".

12. Sebagai upaya untuk memperluas dan menyaring pengetahuan, seorang guru membantu siswa mengembangkan proses penalaran yang kompleks. Penalaran tersebut yaitu; membandingkan, mengklasifikasikan, mengabstraksikan, penalaran induktif, penalaran deduktif, mengkonstruksi, menganalisis kesalahan, menganalsisi perspektif. Bagaimana cara melakukan penilaian dari penalaran tersebut? Jawaban: “ Menilai kemampuan peserta didik dalam mengidentifikasi contoh dan bukan contoh, menduga dan memeriksa kebenaran suatu pernyataan, mendapatkan atau memeriksa kebenaran dengan penalaran".

13. Agar siswa menggunakan pengetahuan secara bermakna, guru perlu membantu siswa mengembangkan proses penalaran kompleks. Apa saja yang dapat dikembangkan dalam penalaran kompleks? Bagaimana cara menilainya? Jawaban: "Pada pelajaran matematika contohnya siswa diberikan tugas perkalian sehingga siswa dapat menalar/berfikir secara kompleks".

14. Agar siswa memiliki perilaku berpikir, guru perlu membantu siswa mengembangkan perilaku berpikir produktif. Apa saja perilkaku berpikir? Bagaimana cara melaksanakan penilaiannya? Jawaban: " $Y a$, siswa mampu berpikir kritis terhadap masalah yang diberikan oleh guru pada pembelajaran".

15. Soal-soal HOTS merupakan instrumen pengukuran yang digunakan untuk mengukur kemampuan berpikir tingkat tinggi, yaitu kemampuan berpikir yang tidak sekadar mengingat (recall), menyatakan kembali (restate), atau merujuk tanpa melakukan pengolahan (recite)? Apakah anda pernah membuatnya? Bagaimana melakukan penilaiannya? Jawaban: "Ya, pertama-tama kita harus menganalisis tingkat kesulitan soal yang akan kita berikan kepada siswa, lalu kita menentukan skor dari setiap soal yang kita berikan".

16. Penilaian keterampilan menggunakan teknik praktik mengutamakan penilaian proses? Apakah anda pernah melaksanakannya? Bagaiman prosesnya? Jawaban: "Ya, proses penilaian keterampilan meliputi; perencanaan penilaian, penyusunan instrumen penilaian, pelaksanaan penilaian, pemanfaatan hasil penilaian dan pelaporan hasil penilaian".

Berdasarkan hasil wawancara tersebut di atas dapat diketahui bahwa sebagian guru telah memperoleh informasi tentang penilaian pembelajaran HOTS, bahkan guru pun telah melaksanakan penilaian tersebut hanya saja mereka belum memahami dengan benar yang mana penilaian pembelajaran yang masuk kategori HOTS

\section{Pembahasan}

Berdasarkan hasil penelitian dapat dijelaskan bahwa proses difusi inovasi penilaian pembelajaran HOTS di sekolah dasar se Kecamatan Banawa belum maksimal, hal ini dapat dilihat dari presentase jawaban yang terdapat pada kuisioner yaitu hanya $40 \%$ guru yang telah memperoleh memperoleh informasi tentang Penilaian Pembelajaran HOTS, 30\% yang memberi jawaban ya tentang apakah dikomunikasikan oleh pemerintah setempat, $65 \%$ yang setuju tentang penilaian Pembelajaran HOTS adalah sesuatu yang baru, meresahkan dan sulit untuk dipahami dan dilaksanakan, $60 \%$ guru yang menjawab ya tentang adanya hambatan ketika Penilaian Pembelajaran HOTS ini dikomunikasikan, hanya $30 \%$ yang setuju dengan pertanyaan apakah telah terjalin pertukaran informasi tentang Penilaian Pembelajaran HOTS dikalangan para guru, $30 \%$ guru yang telah melaksanakan Penilaian Pembelajaran HOTS, $70 \%$ guru yang menjawab ya tentang adanya hambatan dalam pelaksanaan Penilaian Pembelajaran HOTS, $50 \%$ guru yang ketika mengajar membantu siswa mengembangkan sikap dan persepsi positif tentang iklim belajar di kelas, $30 \%$ guru yang setuju bahwa agar siswa memperoleh dan mengintegrasikan pengetahuan, 
guru perlu membantu siswa memperoleh pengetahuan deklaratif, $25 \%$ guru yang membantu siswa memperoleh pengetahuan prosedural.

Secara umum presentase penyebaran informasi atau difusi inovasi penilaian pembelajaran HOTS di sekolah dasar se Kecamatan Banawa hanya mencapai $45 \%$, artinya bahwa transfer informasi kepada para guru dari pemerintah dan stake holder belum maksimal. Masih ada $55 \%$ pemerataan informasi tentang penilaian pembelajaran HOTS yang perlu dijangkau oleh pemerintah maupun stake holder setempat.

Adapun diagram penyebaran informasi HOTS di SD se Kecamatan Banawa dapat dilihat pada gambar 1 di bawah ini.

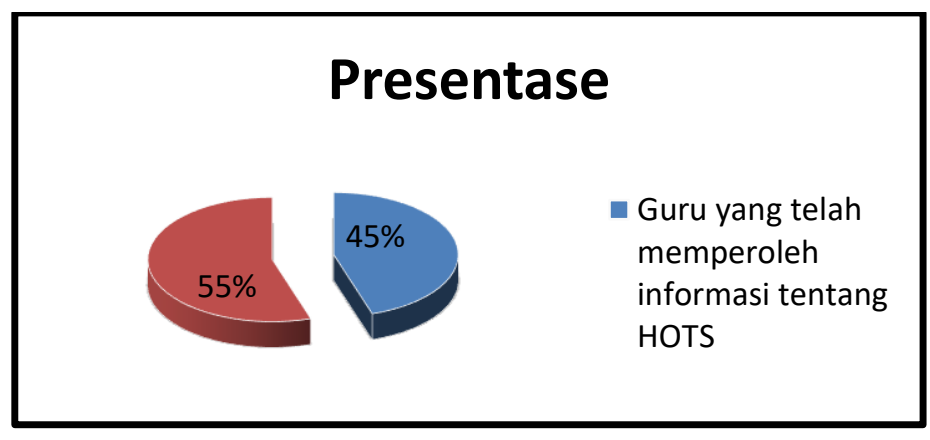

\section{Gambar 1. Presentase Difusi Penilaian Pembelajaran HOTS di SD se Kecamatan Banawa}

Berdasarkan data tersebut dapat dikatakan bahwa penilaian pembelajaran HOTS sudah dilaksanakan hanya saja masih asing bagi para guru. Menurut Setiawati, dkk (2018), bahwa penilaian berorientasi HOTS bukanlah sebuah bentuk penilaian yang baru bagi guru dalam melakukan penilaian. Tetapi penilaian berorientasi HOTS ini memaksimalkan keterampilan guru dalam melakukan penilaian. Guru dalam penilaian ini harus menekankan pada penilaian sikap, pengetahuan dan keterampilan yang bisa meningkatkan keterampilan peserta didik dalam proses pembelajaran berorientasi HOTS.

Dari hasil wawancara juga diketahui bahwa informasi tentang penilaian pembelajaran HOTS diperoleh dari kegiatan KKG. Sebelum memberikan informasi tentang penilaian pembelajaran HOTS terlebih dahulu guru mempersiapkan RPP, pemetaan dan perangkat pembelajaran lainnya untuk dijadikan panduan bagi guru dalam melaksanakan proses pembelajaran.

Sebagian besar siswa sulit memahami pembelajaran soal HOTS, karena dibutuhkan kemampuan siswa untuk untuk memecahkan masalah secara mandiri dengan kemampuan berpikir secara kritis dan kreatif. faktor yang menghambat penilaian pembelajaran HOTS adalah; lingkungan keluarga yang kurang mendukung dan fasilitas sekolah yang kurang memadai, sebagian besar guru belum menerima informasi tentang penilaian pembelajaran HOTS.

Ketika mengajar guru membantu siswa mengembangkan sikap dan persepsi positif tentang iklim belajar di kelas, penilaiannya yaitu dengan cara mengecek kehadiran siswa, sikap siswa dalam kelas, mengecek kerapian siswa, mematuhi peraturan dan perintah yang diterapkan guru. Guru membantu siswa mengembangkan sikap dan persepsi positif tentang tugas-tugas belajar di kelas. Proses penilaian HOTS pendekatan saintifik (5m) yang meliputi; mengamati, menanya, mengumpulkan informasi, menalar dan mengkomunikasikan sehingga mampu mengubah iklim pembelajaran menjadi lebih aktif, kolaboratif dan partisipatif sehingga merangsang kemampuan berpikir kritis dan analisis siswa.

Sebagai upaya untuk memperluas dan menyaring pengetahuan, seorang guru membantu siswa mengembangkan proses penalaran yang kompleks. Penalaran tersebut yaitu; membandingkan, mengklasifikasikan, mengabstraksikan, penalaran induktif, penalaran deduktif, mengkonstruksi, menganalisis kesalahan, menganalsisi perspektif. Menilai kemampuan peserta didik dalam mengidentifikasi contoh dan 
bukan contoh, menduga dan memeriksa kebenaran suatu pernyataan, mendapatkan atau memeriksa kebenaran dengan penalaran. Proses penilaian keterampilan meliputi; perencanaan penilaian, penyusunan instrumen penilaian, pelaksanaan penilaian, pemanfaatan hasil penilaian dan pelaporan hasil penilaian".

Berdasarkan pemikiran Rogers dalam proses difusi inovasi, peneliti menyimpulkan bahwa (1) inovasi; Penilaian pembelajaran berorientasi HOTS di SD se Kecamatan Banawa belum difahami dan terlaksana, (2) saluran komunikasi; pemerintah dan stake holder serta pihak sekolah belum memanfaatkan saluran informasi yang ada untuk menyampaikan dan bertukar informasi tentang HOTS, (3) jangka waktu; diperlukan cukup waktu untuk menyalurkan informasi tentang HOTS agar terbentuk difusi inovasi (4) sistem sosial; dalam hal ini sistem sosial atau kerja kelompok guru (KKG) belum maksimal menjadi wadah dalam menyalurkan informasi tentang penilaian HOTS di SD se Kecamatan Banawa Kabupaten Donggala

Pemikiran tersebut didukung oleh hasil wawancara terhadap beberapa guru yang berpandangan bahwa penilaian pembelajaran Hots sangat sulit untuk dilaksanakan dengan kondisi lingkungan dan daya baca siswa yang masih rendah. Oleh karenanya keberhasilan pembelajaran ternyata tidak cuma terkait dengan metode dan strategi mengajar yang tepat, tapi juga terkait pendekatan terhadap pola pikir guru dan siswa itu sendiri. Carol Dweck menjelaskan tentang dua pola pikir beku dan pola pikir berkembang. Guru dengan pola pikir beku percaya bahwa talenta dan kecerdasan mereka statis dan tidak bisa dirubah. Mereka melihat tantangan sebagai hal negatif bukan sebagai kesempatan untuk berkembang. Mereka menghindari rintangan karena mereka takut jatuh dan tidak berusaha keras. Mereka berpikir siapa dan bagaimana mereka dilahirkan adalah penentu kesuksesan mereka, bukan seberapa keras usaha mereka. Individu seperti ini tidak mencapai potensi penuh dalam dirinya. Namun berbeda dengan pola pikir berkembang, guru akan berpikir optimis dan pantang menyerah dan tidak takut menghadapi rintangan. Menurut Carlos Dweck, Dalam pola pikir ini, situasi yang ada ada pada saat ini adalah tahap untuk perkembangan. Pola pikir berkembang ini didasarkan pada kepercayaan bahwa kualitas dasar anda adalah hal yang bisa anda kembangkan lewat usaha. Walaupun setiap orang mungkin berbeda-beda (dalam bakat, kemampuan,minat atau tempramen) setiap orang bisa berubah dan tumbuh berkembang lewat penerapan dan latihan"

Guru mesti menghindari diri dari fixed mindset atau pola pikir tetap ini. Guru yang berpola pikir tetap ini memandang bahwa kecerdasan, karakter dan kemampuan kreatif siswa adalah kapasitas yang tidak berubah, bawaan lahir dan memberlakukan siswa demikian juga. Siswa yang mengalami pendekatan ini pada akhirnya bepikir demikian juga, yang terpenting baginya adalah kelihatan pintar. Mereka pada akhirnya cenderung menolak belajar sesuatu yang baru, karena kalau gagal takut dianggap bodoh. Biasanya mereka menjadi malu kalau gagal atau tidak mengetahui sesuatu yang ditanyakan kepadanya. Para pendidik mengarus utamakan pendekatan growth mindset atau pola pikir berkembang, yang melihat kecerdasan, kepribadian dan karakter seseorang atau siswa berproses untuk besar tumbuh karena tantangan dan kegagalan. Siswa tidak cuma dilihat berhasil dan tidaknya berdasarkan prestasinya tetapi proses dan kegagalan-kegagalannya dianggap sebagai batu loncatan untuk memperluas dan menajamkan kemampuan yang sudah ada. Kecerdasan dan kemampuannya akan terus berkembang seiring proses-proses yang bisa jadi penuh kegagalan.

Guru musti lebih sering memberikan dukungan pada proses bukan pada hasil. Evaluasi terhadap murid sebaiknya terfokus pada perencanaan, proses, usaha, kemajuan dan strategi siswa dalam menghadapi tantangan. Bukan kemampuan atau hasil yang dicapai. "Kalau kita lebih sering memuji perencanaan dan proses, maka siswa akan terbiasa merencanakan dan ikut dalam kegiatan pembelajaran dengan lebih baik. Berikutnya menciptakan lingkungan kelas yang menerima kesalahan. "Apabila kesalahan dianggap biasa, murid tidak akan takut untuk bertanya dan belajar sesuatu yang baru, hal selanjutnya adalah memastikkan bahwa para siswa cukup tertantang di kelas. Buat mereka memahami bahwa tugas yang sulit adalah kesempatan untuk melatih otak dan 
mempelajari hal baru. Hal ini akan terlaksana jika guru berada pada pola pikir berkembang, yang selalu siap menerima perubahan dan berbagai inovasi pembelajaran termasuk penilaian pembelajaran HOTS, mampu beradapatasi terhadap perubahan dan mengembangkan diri sehingga dapat menerapkan perubahan dan inovasi dalam pembelajaran

\section{SIMPULAN DAN REKOMENDASI}

Hasil penelitian menunjukkan bahwa sebagian guru telah memperoleh informasi tentang penilaian pembelajaran HOTS, bahkan guru pun telah melaksanakan penilaian tersebut hanya saja mereka belum memahami dengan benar yang mana penilaian pembelajaran yang masuk kategori HOTS. Dari 30 Sekolah Dasar yang ada di Kecamatan Banawa hanya 13 sekolah atau 45\% yang telah mengenal dan memperoleh informasi tentang penilaian pembelajaran berorientasi HOTS.

Berdasarkan kesimpulan tersebut, peneliti menyarankan (1) Agar pemerintah lebih memaksimalkan sosialisasi tentang penilaian pembelajaran HOTS, (2) Agar guru lebih aktif mencari informasi tentang penilian-penilaian pembelajaran terbaru, contohnya penilaian pembelajaran HOTS

\section{DAFTAR PUSTAKA}

Arikunto, S. (2004). Dasar-dasar evaluasi pendidikan. Jakarta: Bumi Aksara.

Creswell, J. W. (1994). Research Design: Qualitative \& Quantitative Approaches. London: Sage Publications.

Desstya, A. (2015). IPA dan Pembelajaran Berpikir Tingkat Tinggi (Telaah Buku Siswa SD Kelas IV Tema 3, Karya Much. Azan, Dkk). Prosiding Seminar Nasional Pendidikan Sains 2015. Surakarta: 19 November 2015. Hal. 259-266.

Heong, Y.M., dkk. (2011). The Level of Marzano Higher Order Thinking Skills Among Technical Education Students. International Journal of Social and Humanity, 1(2), 121-125.

Kurniati, D., Harimukti, R., \& Jamil, N. A. (2016). Kemampuan Berpikir Tingkat Tinggi Siswa SMP di Kabupaten Jember dalam
Menyelesaikan Soal Standar PISA. Jurnal Pendidikan dan Evaluasi Pendidikan, 20(2), 142-155.

Miles, M. B., Huberman, A.M., dan Saldana, J. (2014). Qualitative Data Analysis, A Methods Sourcebook, Edition 3. USA: Sage Publications. Terjemahan Tjetjep Rohindi Rohidi, UI-Press.

Mulyasa, H. E., Iskandar H. D., \& Aryani W. D. (2016). Revolusi dan Inovasi Pembelajaran. Bandung: PT Remaja Rosdakarya

Pemendikbud nomor 104 Tahun 2014 tentang Penilaian Hasil Belajar oleh Pendidik pada Pendidikan Dasar dan Pendidikan Menengah.

Pratama, Nurris S., \& Istoyo E. (2015). Studi Pelaksanaan Pembelajaran Fisika Berbasis Higher Order Thinking (HOTS) Pada Kelas X di SMA Negeri Kota Yogyakarta. Prosiding Seminar Nasional Fisika dan Pendidikan Fisika, 6(1), 104-112.

Rogers, E. M. (1983). Diffutions of innovations. 3rd Edition. New York: The Free Pass A Division of Macmillan Publishing Co, Inc. 